\title{
Church Associations Struggling with Unity in the Uniting Presbyterian Church in Southern Africa (UPCSA) between 1999 to 2015
}

\author{
Karabo M. Makofane \\ https://orcid.org/0000-0003-4747-3326 \\ University of South Africa \\ Makofkm@unisa.ac.za
}

\author{
Graham Duncan \\ https://orcid.org/0000-0002-2583-1914 \\ University of Pretoria \\ profgrahamduncan@gmail.com
}

\section{Abstract \\ This article analyses the conflict which arose as a result of the attempt to amalgamate the church associations in the Uniting Presbyterian Church in Southern Africa (UPCSA) between 1999 and 2015, following the union of the black Reformed Presbyterian Church in Southern Africa (RPCSA) and white dominated Presbyterian Church in Southern Africa (PCSA) in 1999. This process has been hindered by problems that have plagued the anticipated union of the church associations that appear to conform to former denominational lines. Historically, the associations have been the vanguard of mission in both former denominations. This article will argue that structural unity in the UPCSA has by and large been unable to assist in overcoming some of the old divides between the former two denominations. As a result, this has the potential to test the witness and have a serious negative impact on the mission of the UPCSA.}

Keywords: Uniting Presbyterian Church in Southern Africa; Presbyterian Church in Southern Africa (UPCSA); Reformed Presbyterian Church in Southern Africa (RPCSA); associations; Uniting Presbyterian Women's Fellowship; Men's Christian Guild

\section{UNISA $\cong$}




\section{Introduction}

This article is dedicated to the memory of our late colleague, Mary-Anne Elizabeth Plaatjies-Van Huffel, who passed away in 2020. Plaatjies-Van Huffel was a theologian and a church leader with whom we have become closely acquainted through the Church History Society of Southern Africa (CHSSA). One of the enduring legacies of PlaatjiesVan Huffel was her commitment to church unity. The role she played during unity talks with the Dutch Reformed Church (DRC) in her tenure as the moderator of the Uniting Reformed Church in Southern Africa (URCSA) was phenomenal. In deep appreciation of Plaatjies-Van Huffel and in honouring her scholarly contributions, we saw fit to revisit this topical issue by focusing on the process of unification of church associations in the Uniting Presbyterian Church in Southern Africa (UPCSA).

According to Xapile (1994, 35), already in the 1960s, the joint committee on union negotiations of the former Presbyterian Church in Southern Africa (PCSA) and Bantu Presbyterian Church in Southern Africa (BPCSA), which was renamed Reformed Presbyterian Church in Southern Africa in 1979 (RPCSA), was positive that the integration of associations of the two former denominations would prove to be an easy process, since they had similar names and character. However, given the different value systems, histories and traditions which were in operation among the different associations in the RPCSA and the PCSA, it would be far from easy to amalgamate various church associations in the new denomination, as evidenced by conflicts that have dogged the process of the integration of various associations within the UPCSA and appear to be along the former denominational lines.

What exacerbated and frustrated the process of amalgamation of church associations in the new church among other things, was the fact that the Executive Committee of the Special Commission on Union (ECSCU), which was tasked by the General Assembly to facilitate and guide the process of uniting various associations, failed to carry this mandate (UPCSA, GA 2000, 236). The ECSCU in 2000 apologised to the General Assembly for its failure to take the initiative at the right time to guide the associations in the process of amalgamation (UPCSA, GA 2000, 236). As a result, other alternatives were explored through various other structures such as the Church Association's Working Group (WG) of the denomination with the aim of assisting in integrating the different church associations in the UPCSA, but up to 2015, have not succeeded. According to Duncan $(2005$ b , 202) by June 1999, two months prior to the union, only the men's association had made progress This article will argue that some of these conflicts which have plagued church associations within the UPCSA, indicate that structural unity in the UPCSA has by and large not been able to assist in overcoming some of the old divides between the former two denominations.

What is the nature of these conflicts? Are there any available interventions to address them in order to strengthen the already achieved unity which is under threat? For the purpose of this article, issues such as uniforms, poor communication, issues of representation, the Manual of Faith and Order (2007) and the so called third force were 
identified as some sources of conflict which threaten to hamper the process of the amalgamation of associations within the UPCSA.

Furthermore, in dialogue with two men's and women's associations within the UPCSA, namely the Uniting Presbyterian Women's Fellowship (UPWF) and its precursors, the Women's Christian Association (WCA) of the RPCSA, and the Women's Association (WA) of the PCSA respectively; and the Men's Christian Guild and its forerunners, Presbyterian Men's Association (PMA) of the PCSA and the Young Men's Christian Guild (YMCG) of the RPCSA, the article will demonstrate how the abovementioned challenges were, among other things, a key obstacle in the process to merge the aforesaid associations. When it is considered that these associations formed the primary instruments of mission within the black community, the current disputes drain the energy required to maintain and promote mission. The article will attempt to give an assessment of factors that have hindered the integration of the associations under discussion and propose a way forward in this connection.

\section{A brief History of the Associations under Discussion}

According to Buqa $(2012,2)$ in many churches there are structures, which are predominantly espoused by the black membership, though their membership is not restrictive. These structures are called church associations and their activities fall under their constitutions, which have been approved by and are under the authority and discipline of the General Assembly of the denomination. Buqa $(2012,2)$ maintains that the UPCSA has such church associations that have played a significant role in both the growth and development of the church. Various church associations, such as the Women's Association and Men's Association, form part of many black congregations within the UPCSA. There are associations in the white congregations of the denomination, but these do not have a missionary function. They exist largely for social and educational purposes. The erstwhile PCSA had both white and black branches of the UPWF, with different activities and emphases, unlike the RPCSA.

Vellem $(2007,44)$ asserts that church associations have a long and proud history in the life and work ministry of the black church. Preston (2007, 3) states that church associations have provided a place of respect, recognition and support for many members of the church. In most congregations, church associations are the pillars of strength of the church; they are involved in the entire life and work ministry of the local church. They are the bodies whose outreach activities link most easily with communities at their grassroots. They have historically connected with people in need and have provided pastoral, spiritual and evangelical support. This support has been, for the most part, offered through prayer and preaching. There are differences of opinion as to when church associations began. According to one legend, once black people were infected by the Christian bug, they would often meet informally to share their stories and experiences about God. Church associations played an instrumental role in the development and growth of black church leaders in the UPCSA (Buqa 2012, 4). Among them are: Rev. Prof. M. Masango, emeritus professor in the Department of Practical 
Theology at the University of Pretoria; the late Rev. Prof. V. Vellem, the former General Secretary of the UPCSA and a staff member at the Faculty of Theology at the University of Pretoria; Rev. Dr S Xapile, attached to Stellenbosch University on a part-time basis; and Rev. Col. Z Makalima, the Director of the South African Air Force Chaplains.

\section{Uniting Presbyterian Women's Fellowship (UPWF)}

Although the PCSA-RPCSA merged to form the UPCSA in 1999, by 2000 the WA of the former PCSA and the WCA of the former RPCSA were not yet united and have continued to function separately (UPCSA, GA 2000, 93). This caused major problems in most presbyteries, with certain branches not understanding why this had to be the case. An initial meeting was held in October 1999 in Alice, Eastern Cape, in an attempt for the leaders of the two separate associations to meet and discuss issues relevant to unification (UPCSA, GA 2000, 93). At this meeting it was agreed that the Uniting Women's Working Committee, consisting of five representatives from the two women's organisations, would be put in place.

The committee met for the first time in February 2000, which turned out to be a fruitful time of decision making and relationship building. This was the beginning of a process towards the amalgamation of these two associations (UPCSA, GA 2000, 93). The outcome of this process, with the help of the Special Commission on Union (SCU) was to lead the WA/WCA amalgamation team to produce a draft constitution for the proposed new Women's Association, which was submitted to the Annual General Meetings (AGMs) of the WA and WCA, which took place from 29 June to 4 July 2002 (Zambia) and 5-7 July 2002 (Pietermaritzburg) respectively (UPCSA, GA 2002, 15). The Presbyterian Women's Association AGM adopted the draft constitution on the condition that some amendments were made to it. They mandated the negotiating team to finalise the draft constitution and submit it to the 2003 Executive Commission. Similarly, the WCA AGM adopted the draft constitution as an interim constitution (UPCSA, GA 2002, 15).

The WCA also resolved, however, to give its individual members and presbytery structures time, up to 5 August, to study the draft constitution further and submit their comments to the negotiating team to take into account when finalising the draft of the constitution. As a way of strengthening relations, the negotiating team proposed to the WA and WCA AGMs that they planned to hold their Uniting Conference in July 2003, and the two AGMs adopted the proposal.

It has to be noted that the WA-WCA amalgamation had been much more difficult to bring about than those of any other organisations, partly due to the highhanded actions of the then Executive Committee and their extreme reluctance to co-operate with the SCU (UPCSA, GA 2004, 378). After they had written a letter of complaint to the 2000 General Assembly, the full SCU met with them the following February and members of the executive attended part of the WCA conference (AGM) in July. That meeting agreed 
to resume negotiations with the WA, but a meeting with the WA and the SCU Executive was cancelled at the last minute (UPCSA, GA 2004, 379).

The 2001 Assembly lost patience with the WCA Executive and strengthened the arm of the SCU to take whatever measures were necessary, including discipline. At a meeting of WCA Presbytery representatives a new negotiating team was elected and talks resumed under the guidance of the SCU. The end result was the amalgamation of the WA and WCA to form the Uniting Presbyterian Women's Fellowship (UPWF) in August, 2003 (Report of the Special Commission on Union, UPCSA, Proceedings and Decisions of the 6th General Assembly 2004, 379).

According to the report of the UPWF to the General Assembly of 2005, the UPWF has a large membership made up of about 340 branches spread through all 18 presbyteries of the UPCSA (including Zambia and Zimbabwe) and is one of the recognised associations of the UPCSA (UPCSA Proceedings and Decisions of the Executive Commission 2005, 45). The General Executive meets once a quarter and additionally, whenever there is a need for a meeting. The co-presidents take turns to chair the meetings (UPCSA, Papers, Proceedings and Decisions of the Executive Commission 2005, 47). The UPWF sponsors a number of projects, which include educational, community building and membership capacitation. The fellowship gives financial support to UPCSA projects like the retired ministers' fund.

\section{The Men's Christian Guild}

Based on the Basis of Union document, Art 13, the former RPCSA Young Men's Christian Guild (YMCG) and the Presbyterian Men's Association of the former PCSA started the discussions on the formation of one Men's Guild in the new denomination (Report on the Mediation Work of the Uniting Presbyterian Church in Southern Africa to the 11th General Assembly of 2014, 86). An interim committee was elected to facilitate the unification. Unfortunately, the process was not as smooth as had been envisioned. However, both associations (YMCG and PMA) were committed to the formation of one men's association (Report on the Mediation Work of the Uniting Presbyterian Church in Southern Africa to the 11th General Assembly of 2014, 86).

The name of the association, Men's Christian Guild (MCG), and the badge were agreed upon. However, the colour of the uniform (notably, white or black jacket) became a contentious issue. A task team was appointed to look into and report back on this matter at the conference of 2004 in Umtata. Unfortunately, it failed to discharge its mandate. As a result, the conference was dominated by disagreements and talks nearly collapsed (Report on the Mediation Work of the Uniting Presbyterian Church in Southern Africa to the 11th General Assembly of 2014, 86). In the 2005 conference, the issue was revisited, inputs were made and in 2006 at the Western Cape conference it was ratified and the MCG was formed. Sadly, some members of the former PCSA did not join the new MCG but opted to form the Uniting Presbyterian Men's Fellowship (UPMF), which is a replica of MCG but is not recognised by the General Assembly of the UPCSA. 
Negotiations are ongoing with the hope that UPMF and MCG will become one for the sake of cohesion and unity (General Secretary Report to the Assembly, Papers, Proceedings and Decisions of the Executive Commission 2007, 182).

Some of the aims of the MCG, according to Buqa $(2012,138)$, are inter alia:

- To present Jesus Christ as the Lord and Saviour of men and to engage them in the promotion and extension of God's kingdom.

- To extend the kingdom of God, in our Church and in the Churches to which we are related and the entire world.

- To build up Christian character by encouraging attendance at public worship, the reading of scripture and witness to Christ.

- To include a sense of moral discipline, especially in the members of the Guild.

- To promote programmes of intellectual, social and physical growth.

These encapsulate the missionary dimension of this association. The focus is on outreach and drawing men into the church with its prime focus of advancing the coming kingdom of God. It has a reconciliatory dimension that lies at the heart of the missio $D e i$. The aims of the other associations are similar.

\section{Membership}

- Membership shall be open to all ministers and male members in full communion.

- Each branch together with its outstations shall take the name of a congregation to which it belongs.

\section{Uniforms}

According to Duncan $(2006,937)$, dress has always been a way in which people of a particular time and place express their identity. Similarly, Buqa $(2012,3)$ maintains that the identification of church associations is also marked by the culture, beliefs and values of black people in the church as part of their spiritual growth. Uniform has always been a form of identity in many associations of black churches. Members of each association wear a uniform particular to their own denomination (Buqa 2012, 3). They are distinguished by their particular uniform. Buqa $(2012,3)$ holds that church association groups often decide on the colours and design of the uniform. This was to become a source of conflict among the associations in the UPCSA, in particular between the UPWF and the MCG.

In the report on church associations, it was noted that the uniform issue was still the main challenge facing the church associations (Uniting Presbyterian Church in Southern Africa, Papers, Proceedings and Decisions of the Executive Commission, 2009, 18). This issue became so serious that some members of the former PCSA disaffiliated themselves from the UPWF and founded a parallel structure called Uniting Presbyterian 
Women at Work (UPWW) (UPCSA, Papers, Proceedings and Decisions of the Executive Commission, 2009, 18). Buqa $(2012,60)$ claims that many members of the former PCSA remain reluctant to give up the uniform of their former denomination. As a result, they have not embraced the new uniform of the UPCSA, which they feel has a striking resemblance with the uniform of WCA of the former RPCSA.

According to the report of the UPWF to the General Assembly of 2008, the annual conference which took place from 31 July to 3 August 2008, the following uniform was adopted (UPCSA, Papers for the 8th General Assembly 2008, 247):

- Black hat.

- Belt with two buttons.

- Black under collar.

- Black skirt.

- Black stockings.

- Black shoes.

According to Buqa $(2012,113)$, the uniform of the women from the former RPCSA WCA was:

- Black hat.

- White blouse with five buttons.

- A WCA women's badge.

- A white girdle along the waist.

- Black skirt.

- Black shoes.

- Black stockings.

Members of WA of the former PCSA used to wear:

- A white hat.

- A white blouse with a round neck and black under collar.

- A WA badge.

- A white belt around the waist of the blouse with two buttons in front.

- A black skirt.

- Black shoes.

- Black stockings completed the uniform. (Buqa 2012, 113)

Even though there is a slight difference between the uniforms of the women's associations of the two former churches, Buqa $(2012,113)$ points out that the UPWF report indicated that in all presbyteries the black congregations who came from the former PCSA had raised their grievances about the uniform colours and design. As a result, there are a number of fellowship members from the former PCSA who have disaffiliated themselves throughout the new denomination. It is against this background 
that the General Assembly of 2004, even though commending the SCU for helping with the amalgamation of the associations, noted that issues around uniform need to be dealt with more carefully and sincerely (UPCSA, Papers for the 6th General Assembly 2004, 178).

Buqa $(2012,61)$ indicates that in one interview he conducted, the informant mentioned that at times in the UPWF conferences the members would vote for a person based on their membership in their previous denomination (i.e., RPCSA-PCSA) without looking at the qualities of a person. The same informant confided in Buqa $(2012,62)$ that she was contemplating taking off the uniform if the association's problem was not resolved, though she understood the implications of being a minister's wife in a black context.

The General Executive report of the UPWF to the General Assembly of 2014 noted a membership decline in the association. This can be attributed, among other things, to the controversy around issues of uniform (UPCSA, Papers for the 11th General Assembly 2014, 259). According to Buqa (2012, 67), the struggle around issues of uniform often discourages some from joining the UPWF, thus denying its missionary function. Buqa $(2012,32)$ points out that issues around uniform in associations also hurt congregations financially; he cites an example where in one congregation some members of the UPWW decided to make no further contributions to denominational funds in order to express their displeasure with the way in which the process of uniforms was handled.

The MCG Executive reported to the General Assembly of 2003 that their inaugural annual conference in 2001 had run into serious difficulties, shortly before the General Assembly, when they tried to finalise the constitution of the MCG and the uniform which would be acceptable to the former two denominations (UPCSA, GA 2003, 87). Disagreements over issues around uniforms led to rising tensions and finally to a walkout of a substantial number of members of the MCG, all former members of the Presbyterian Men's Association Guild of the former PCSA. Representatives of this group handed a petition to the MCG before leaving the conference. They later founded the Uniting Presbyterian Men's Fellowship (UPMF) (Uniting Presbyterian Church in Southern Africa, Papers for the General Assembly 2003, 87).

According to the report of the MCG Executive to the General Assembly of 2008, the following uniform was adopted (UPCSA, GA 2008, 264):

- A white jacket without a vent with two silver buttons.

- A black pair of trousers.

- A white shirt.

- A plain black tie and a black pair of shoes and a black pair of socks and an MCG badge.

- A white waistcoat. 
Buqa (2012, 84-85) has listed the elements of the new MCG uniform taken from the former PCSA and RPCSA.

\section{Elements taken from the former PCSA Men's Association in MGC:}

- Shape of the MCG badge is round like the former PMA.

- The St Andrews cross of the MCG is taken from the former PMA.

- The waist coat of the MCG is totally from PMA.

- The silver buttons of the MCG white jacket are taken from the former PMA.

- The MCG badge has a star taken from the former PMA.

- The name Amadoda in the MCG is taken from PMA.

\section{Elements taken from the former RPCSA Men's Association in MCG are:}

- The MCG name that sounds similar to YMCG of the former RPCSA.

- The colour of the new jacket of the MCG is white like the former RPCSA.

The General Secretary of the UPCSA reported that, in a meeting on 9 March 2007 in Port Elizabeth, he had met exclusively with the members of the Men's Fellowship (which was constituted completely by members of the former PCSA) whose view was that the new uniform of the MGC was not new and accommodated members of the RPCSA (UPCSA, Proceedings and Decisions of the Executive Commission 2007, 188). This view is problematic, if one considers that only two elements were taken from the former RPCSA and six from the PCSA. Therefore, we concur with Buqa $(2012,5)$ that perhaps there are other, deeper issues underlying the church associations' uniforms issue. The report of the mediation team cited fear of losing identity and heritage in the larger associations as one of the reasons. For instance, women of the PCSA disaffiliated themselves from UPWF and formed the UPWW (UPCSA, Papers for the 11th General Assembly 2014, 93). The Men's Association (UPMF), which is dominated by members of the former RPCSA, also indicated to the mediation team that the stumbling block in uniting with the MCG was not uniform but the fundamental problem with the MCG and UPMF is the way both conduct business (UPCSA, GA 2007, 88). Buqa $(2012,104)$ confirms that in some of the interviews he conducted the informants identified governance decision-making processes within the united church, strong Xhosa dominance in the new denomination, power, pride and control as some of the underlying issues - which have nothing to do with uniform.

Some ministers have become entangled in the church associations' uniform debacle, and as a result they have been accused of causing conflict and breeding divisions (UPCSA, GA 2014, 74). Membership of associations such as the MCG and UPWF is open to ministers and their wives - in some cases they even serve in the leadership positions of these associations. Historically, this was mandatory in the RPCSA tradition. However, the danger is that when conflicts arise within church associations it is difficult for them to intervene and be neutral or non-partisan, since they have a conflict of interest. Once ministers are members of a particular association, there is also a 
temptation to transmit distorted information to congregants regarding church associations' conflicts in an attempt to save the credibility and reputation of the association they themselves are affiliated to; and as a consequence, congregants end up being ill-informed regarding church associations' conflicts.

\section{Poor Communication}

According to Sofield and Julianos (in Karecki 1999, 92), poor communication is one of the most frequent causes of conflict. Lack of communication in any organisation or community (including the church) is a central factor in breeding rumours and gossip. When information is not shared in an appropriate manner with the people concerned, then suspicion arises and trust decreases. In this connection, Duncan (2005a, 46) claims that the Special Commission on Union (SCU) was often accused by various groups, including church associations, of failing to communicate and carrying its mandate of facilitating the process of merging different associations in the UPCSA.

This emerged in the healing and reconciliation service of associations held in Tshwane Presbytery in September 2015 at St Mark's Presbyterian Church. At this service, members of various associations shared their pains and hurts regarding conflicts in church associations. Members of different associations mentioned that in the initial stages of the union, the Special Commission on Union (SCU) failed to communicate with the highest structures of different associations regarding the process of merging associations. As a result, members of associations were often in the dark regarding how this process would unfold. The breakdown of the unity negotiations between the Presbyterian Men's Association of the PCSA and the Young Men's Christian Guild of the RPCSA, is also attributed to poor communication on the part of the SCU. To attest to these claims, the executive of the SCU later apologised to the General Assembly of 2000 for failing to initiate the union of the church associations (UPCSA, GA 2000, 236).

Another source of conflict, according to Sofield and Juliano (in Karecki 1999, 92), is "loss." They point out that loss not only occurs when someone experiences the death of a relative or friend, but when things are changed without their consultation or without information being provided. Loss most often causes pain and anger. Duncan (2005b, 203) indicates that some of these sentiments were expressed by the Women's Christian Association of the RPCSA, claiming that they had not been adequately respected and consulted during the period leading to the union. When some members of the PCSA terminated their membership of the UPWF, they cited poor consultation regarding decisions on issues around uniforms and other related matters as a reason why they decided to form the Uniting Presbyterian Women at Work (UPWW), which is not recognised by the UPCSA (UPCSA, GA 2009, 18).

Furthermore, in 2000, Amatola Presbytery which was an amalgamation of two strong presbyteries of the former denominations (the one totally black and the other multiracial yet dominated by whites), experienced problems including the union of women's organisations. According to Duncan $(2005 \mathrm{~b}, 202)$, this related to the role of ministers' 
wives in the respective women's associations of the former denominations. The WCA of the RPCSA claimed that lack of clarity on this issue is a classic example that they had not been adequately consulted during the period leading up to the union (Duncan 2005b, 203). This problem was not only a local matter restricted to Amatola Presbytery, as the Executive Committee of the SCU claimed (in Duncan 2005b, 202) similar issues were emerging throughout the denomination. The Amatola incident just happened to be the tipping point.

In his report to the General Assembly of 2014, the former General Secretary, Rev. Prof. J. Pillay accused some ministers of not sharing information with their congregations on certain matters including church associations (UPCSA, GA 2014, 74). One can only suspect this has to do with the conflict surrounding church associations, especially in cases where some ministers are members of associations. They might not feel free to share with their congregations any information which they deem to be anti- the association they are affiliated to, since they are conflicted by being members of such associations. This is unfortunate, since according to Pillay the denomination relies on ministers to take the lead in distributing and sharing information with their congregations (UPCSA, GA 2014, 74).

Channels of communication are important, especially when they concern the affected party - in this case, members of associations. Those who represent members of associations in the high echelons of the church must always be mindful that they are accountable to them. Failure to account to one's constituency (in this case members of church associations) can result in ignorance, prejudice and rumour mongering, which according to a report of the special committee on reformation, found its way around the denomination far more efficiently and speedily than the "official" communication (Progress Report from the Special Committee on Reformation 2002, 1).

\section{Issues of Representation}

The concern has been expressed that committees of the presbytery and other structures of the new denomination tended to be made up predominantly of either former PCSA or former RPCSA members, rather than a balanced composition (Report of the Special Commission on Union, UPCSA, Proceedings and decisions of the 6th General Assembly 2004, 379). Already in 2000, the first moderator of the UPCSA, Rev. Cliff Leeuw, warned that the impression should not be created that what took place in September 1999 was the incorporation of the RPCSA into the PCSA (UPCSA, Papers for the General Assembly 2000, 323). One can deduce from this statement that Rev. Leeuw was hinting at issues of representation and absorption into the new denomination. Such sentiments were expressed from both the RPCSA and PCSA. For instance, Duncan (2005a, 47) observed that, on the part of the RPCSA, there was a fear that the union may lead to their domination by the predominantly white PCSA. On the other hand, the white members of the PCSA were coming into the union with the feeling that, as a result of the introduction of the new political dispensation, they might lose everything to the former RPCSA, particularly their strong financial base of investments. 
These sentiments pre-date the organic union in 1999; such fears were already expressed during the earlier stages of union negotiations (Xapile 1994, 123). This phobia of absorption or "swamping or swallowing," as expressed by some in the circles of the Uniting Presbyterian Men's Fellowship (UPMF) of which the majority belong to the former RPCSA, has come to haunt church associations. For instance, Buqa $(2012,90)$ argues that the dominance of the RPCSA members in church associations became a sore point, even though it was inevitable that the RPCSA by far had a larger membership in the union, as compared to its counterpart, the PCSA.

The UPMF raised a concern to the mediation team, which had been requested by the General Assembly to mediate between various associations, that the composition of the team (which was initially supposed to break a deadlock pertaining to issues they disagreed with the MCG), was dominated by erstwhile RPCSA members, except one person who belonged to the former PCSA (UPCSA, GA 2014, 87). As a result, the team could not be neutral and make fair decisions. Issues of the majority-minority divide in the PCSA and RPCSA resurfaced again in a meeting that the General Secretary of the UPCSA had with the same UPMF on 2 March 2007. The UPMF indicated that they were committed to one association of men in the UPCSA, but often their input was not valued since they were regarded as a minority by the MCG, which was constituted by a majority of members from the RPCSA (UPCSA, GA 2007, 183).

In an interview that Buqa $(2012,61)$ conducted with a former member of the UPWF, the informant alluded to the fact that at times in the conferences of this association the members would vote along former denominational lines (i.e., RPCSA-PCSA) and since membership of this association was dominated by members of the RPCSA, views from the PCSA were often overlooked. As a result, former denominational divides separated them into churches instead of one denomination, the UPCSA.

The claims that members of the RPCSA have dominated the MCG, and in the process marginalised the UPMF, are questionable. Buqa $(2012,91)$ refutes such claims, since the former presidents of the MGC (between 2004 and 2014) came from the former PCSA. Duncan (2005a, 209) argues that if one were to do a small exercise and list things which the former RPCSA had to give up since the union, we are likely to discover that the union was biased in favour of the former PCSA. For instance, the former RPCSA adopted the manual of faith of the former PCSA, the method of collecting assessments, the method of paying stipends, the General Assembly office of the PCSA, and the PCSA time of meeting for the General Assembly. Therefore, it could be argued, was it not an opportunity for association members of the former PCSA to reciprocate, instead of complaining about being absorbed and out-manoeuvred by ex-RPCSA members in church associations, as the former Moderator Rev. W.D. Pool claimed in his opening moderator's address in 2007 (UPCSA, GA 2007, 260). 


\section{Manual of Faith and Order}

According to Buqa $(2012,16)$, the Manual of Faith and Order is the church polity of the UPCSA approved by the General Assembly in 2004. Vellem (in Buqa 2012, 20) states that both the PCSA and RPCSA approved the Basis of Union. This Basis of Union included the following paragraph on "The Polity of the Church" (Vellem 2007, iii):

The Presbyterian form of church government is held to be founded upon, and agreeable to, the Word of God. The form of government of the Uniting church shall be determined in all matters by a book to be named "The Manual of Law and Procedure of the Uniting Presbyterian Church in Southern Africa." In the interim this will be the Manual of Law and Procedure, as amended by the former PCSA [and] will be replaced by the reference to the Uniting Church. After the union the General Assembly of the Uniting Church will set up a Manual Committee to draw up the new Manual of Law and Procedure of the Uniting Church.

According to Buqa $(2012,20)$, the Uniting Church appointed a Manual Committee in 1999 to prepare the chapters of this manual in a draft form; a process that led to the First Edition Manual of Faith and Order of the Uniting Presbyterian Church in Southern Africa, a new name approved by the General Assembly in 2004.

However, at a later stage it turned out that the Manual of Faith and Order was fraught with limitations. As a result, there were a number of concerns raised against this important document and the manner in which it was applied (Duncan 2005b, 96). A case in point is the omission of church associations in the Manual of Faith and Order. Hence, the MCG Executive Committee (in its report to the General Assembly of 2008) expressed a concern that the Manual of Faith and Order (in its 18 chapters) does not have a single chapter or section dedicated to the associations, which are an important component of the church and have contributed to the growth and development of the church, both materially and spiritually (UPCSA, GA 2008, 266).

The report of the Executive Committee of the MCG further notes that:

- The existence of church associations is not recognised in the manual with the risk that their existence can be viewed as illegal.

- The manner in which church associations as bodies relate to the church councils at multi-national, synodical, presbyterial and congregational levels is not regulated in the manual.

- The manner in which church associations are represented in the church councils and how they report, as well as the kinds of reports they are expected to submit and the frequency of reporting, are not regulated by the manual.

- The manual is silent on the kind of ministry that the personnel of the denominations, especially the ministers, are expected to give to the church associations. 
- The status of the "Constitution" of the church associations in relation to the Manual of Faith and Order is not spelt out. This must entail an expression of the superseding role of the Manual of Faith and Order to regulate those areas in which the constitutions of the associations may fall short.

- The manner in which disputes arising within the church associations may be channelled to the church councils, and the avenues available to the church councils in dealing with such disputes, are not spelt out.

- The existence of the Church Associations Committee is not given effect to in the Manual of Faith and order.

- The Manual of Faith and Order does not have a deadlock-breaking mechanism.

Even though the Church Associations Working Group in its report (UPCSA, GA 2015, 61) suggested that the process of writing a chapter on church associations must be suspended until the process of writing the constitutions for the church associations had been completed, this article would argue in the light of the above concerns raised by the MCG executive - pertaining to the omission of church associations in the Manual of Faith and Order and the gravity of conflicts thereof-it is vitally important and urgent that the General Assembly, through the Church Associations Committee, revise the Manual of Faith and Order in a manner that reflects how associations relate to church councils at all levels. This process, among other things, explores possibilities of convening a summit of church associations that will jointly reflect on the state of church associations in the UPCSA and develop proposals for the Manual Committee on issues that the church associations would like to reflect in the revised manual.

\section{Third Force}

Within the circles of the UPCSA there are diverse opinions on what constitutes a third force. On the one hand, it refers to conservative white congregations who do not wish to be swallowed up by a black majority in the UPCSA, and thus see a disruption of the union as a possible way out. This is conceivable, because many PCSA congregations hold the title deeds to their properties and would take the buildings and land with them if they seceded from the union. On the other hand, all of the properties of the RPCSA were, and remain, vested in the General Trustees of the denomination and are subject to their control at the denominational level. On the other hand, according to Buqa (2012, 105), it refers to former RPCSA members who feel that they have lost autonomy and heritage in the process of the union, and they now seek to reverse the process. Lastly, the term is also used to refer to those who are afraid of being swallowed up by a singularly strong Xhosa constituency, subsequent to the union. In the case of the conflicts which have dogged the church associations in the UPCSA, the term "third force" is applied more or less to the first definition proposed by Buqa $(2012,105)$.

Even though the majority of white members do not belong to church associations, given their history with the black section of the PCSA - which by and large was shaped by a politics of domination - they somehow became entangled in the denominational politics 
and conflicts of the church associations. A minority of white members are perceived to be exploiting the conflicts in church associations as an attempt to counter the black majority, whose strength lies in church associations (UPCSA Debate Conference, Eston 28-31 May 2007). In an interview that Buqa $(2012,75)$ conducted with a member of one church association, the informant indicated that some whites knew that if the membership of associations was divided, they could use them for votes to reclaim positions of power in the General Assembly and other powerful church structures.

This article will argue that the "third force" element in church association conflicts is traceable to power relations between whites and blacks of the former PCSA. Although the PCSA became a preponderantly white settler/colonial church, it subsequently planted missions among indigenous people. These missions were denied the full status of congregations for many years. They were supported by and became financially dependent on their parent congregations (Buqa 2012, 29). As a result, the whitedominated PCSA always sought to control, maintain and perpetuate a dependency syndrome over black congregations within their ranks, since they were regarded as the product of their mission enterprise. The consequence of this pattern of mission between the white and black congregations in the PCSA was often marked by paternalistic tendencies and relationships of domination. In some cases, relationships of dominance across racial lines within the denomination manifested in the form of finances, as the former moderator, Rev. Prof. G. Duncan, noted in 2004 in his retiring moderator's address (UPCSA, GA 2004, 468):

And we are beginning to forge relationships within the denomination and co-operate more across racial lines. But, sadly this is a relationship that is too easily based on finance and we need to move beyond that to the formation of a new culture of habit and thought through the development of better relationships, not just of like with like, but through compassion where we learn to feel for and with "the people we most avoid."

Thus, money became a means of exercising power and control over black congregations, rather than a means of liberating them. We would argue that this can be attributed to inter alia a traditional understanding of mission, which according to Duncan $(2007,55)$ has been practised as a current flowing only in a single direction: from North to South, from the rich to poor, from the powerful to the powerless, from male to female, from white to black, from "Christian" civilisation to godless cultures. This understanding of mission has limitations, since it reduces mission to something that some people do to others, rather than a common sharing in God's mission to the whole world.

Secondly, paternalistic mission structures can also be traced from this problematic skewed view of mission. Makofane $(2009,89)$ maintains that this outdated model of mission perpetuates a vicious cycle of dominance and dependence, which in turn further breeds complexes of superiority and inferiority on the part of both white and black congregations. Buqa $(2012,71)$ recounts an incident in February 2009, where a member of an association refused to be charged for misconduct by a white minister (who was 
then a clerk of his presbytery) since he perceived him to represent the third force and has nothing to do with church associations business.

In his moderatorial address to the General Assembly in 2007, Rev. W.D. Pool remarked that he had noted that at the MGC conference to which he was invited, he could only account for a handful of ex-PCSA members who were present (UPCSA, GA 2007, 260). What one can deduce from his remarks is that he took a keen interest in the issues of associations, even though he was not a member of any. He further claimed that perhaps members of the PCSA were absent because they had been outmanoeuvred by the exRPC members in the associations. Pool's observation might be exactly correct. However, the tone of his remarks, relating to lack of participation by ex-PCSA members at this event, points to the perception of "swamping-swallowing" by a majority who happen to be former RPCSA members in the abovementioned association. This might tempt one to affirm a third force factor in the conflict relating to church associations.

In the same healing and reconciliation service at St Marks Presbyterian Church in Tshwane Presbytery (mentioned above), some of the church association members in their testimonies confessed that often they were approached by a few white members, including ministers, not to co-operate with the MCG or UPWF, since these two are dominated by the RPCSA. They claimed that a few white members and ministers often tried to influence some members of the black section of the former PCSA not to join either the MCG or UPWF, since according to them the two associations have eroded the heritage and tradition of the PCSA.

Although there is no clear evidence, there is a deep suspicion that there is a third force operating in the denomination, which has the aim of destabilising the union. That suspicion is founded on the disparity between the men's associations which had united prior to union, but separated soon afterwards without any clear rationale for doing so. There is anecdotal evidence that a former moderator of the UPCSA General Assembly (from the PCSA tradition) informed a president of the Men's Association (from the RPCSA tradition) that the issue of division was denominationally determined by white ministers and elders of the UPCSA, who feared the rise of a black majority in the UPCSA. The denominational split thus prevented the formation of a united black body of membership. The lack of evidence is problematic here, but several questions arise in this context. Who gains from this situation? Whose interests are served? What are these interests? Within the UPCSA the associations are dominated numerically by those from the RPCSA tradition. This caused a rift in the 2003 annual meeting of the Men's Association at Polokwane, where members from the PCSA tradition staged a walk out. This was continued in the following annual meeting in Umtata. This led to the designation of the PCSA tradition association members, naming themselves and known throughout the UPCSA as "the aggrieved" (UPCSA, GA 2003, 87). 


\section{A Missiological Reflection on Situations of Conflict}

Even though there have been concerted efforts by the leadership of the UPCSA to bring reconciliation among warring factions in church associations, it is equally important for the UPCSA to tap into theological resources which can help to address some of these challenges. The Bible is one such important resource that the UPCSA can mobilise to address conflict situations, such as the one which has engulfed church associations. This is valid for the simple reason that the Bible is accessible in a diversity of languages and cultures represented in the UPCSA; therefore, it addresses quite a diverse audience in this denomination. Biblical passages that are fraught with encounters that cultivate a spirit of reconciliation can be useful. One biblical passage that Kritzinger $(2011,7)$ has identified and finds empowering in situations of conflict, is Acts 9:10-19 between Ananias and Saul.

According to Kritzinger $(2011,8)$, when we think of the miracles in the New Testament, we usually think of Jesus healing the sick, the blind and the lame; or even raising the dead. However, one of the greatest miracles in the New Testament happened when Ananias, the Christian disciple in Damascus, walked down Straight Street into the home of Judas, laid his hands on Saul and said to him "Brother Saul." It was not easy for Ananias to do that, given the fact that as a persecuted follower of the Way, he witnessed Saul persecuting fellow Christians and he nearly became a victim of Saul's fierce persecution of the church. You can imagine him saying to the Lord: "Lord, Saul is the enemy. You know how much harm he has done to your people in Jerusalem; and now he has come to Damascus to arrest us also. How do we know he is not trying to infiltrate our group by pretending to be a disciple, so that he can arrest all of us?" But the Lord convinced him to go and pray for Saul, his former enemy and persecutor. The miracle of reconciliation takes place as Ananias places his hands on his former enemy and calls him "brother." This is the kind of miracle that conflict-ridden associations in the UPCSA need today. To recognise that at the heart of God's work of reconciliation, through Jesus Christ, there is the fundamental belief that people can change and that enemies can become friends.

However, Kritzinger $(2011,15)$ cautions us that this does not mean that forgiveness is always easy. Ananias talked back at the Lord, and objected when the Lord told him to go and pray for Saul. With a robust spirituality reminiscent of the Psalms, Ananias wrestled with the Lord about this. Reconciliation is not a superficial "kiss and make up" exercise for the sake of peace. When reconciliation is sincere and driven by values such as honesty, it is always accompanied by pain, sometimes even by confrontation, since reconciliation is about the healing of wounds and the restoration of broken relationships. Hence, Duncan $(2005 b, 39)$ warns that consequently it cannot be done hastily. It is also about the struggle against my own refusal to reconcile, to find a way out of the dark cave of my hatred in which I hide from God and my neighbours (Kritzinger 2011, 15). Perhaps this partly explains why the amalgamation of church associations has dragged on for so long; people are still dealing with their pain caused by conflicts in church 
associations and indeed they must be afforded time to work and struggle towards unity and find closure.

Restoration of relationships between people may often require people who have conflict resolution skills. At the end of Acts 9, a reconciling figure by the name of Barnabas displays mediation skills, reconciling the converted Saul and the congregation in Jerusalem. Kritzinger $(2011,15)$ notes that it must have been difficult for the Christian community in Jerusalem to welcome Saul in their midst, and understandably so, given the kind of harassment as well as the various forms of abuses and the arrests they were subjected to (Acts 8:8). It was there that he approvingly witnessed the stoning of Stephen and the scattering of the early Christian community (Acts 8:1). How could the congregation that was left in Jerusalem forgive and accept him?

There are many such broken relationships in the world. And they often are not healed, unless someone comes from the outside to take the initiative as a mediator. According to Kritzinger $(2011,16)$, Barnabas was such a mediator, a peacemaker who took the initiative to bring the two warring parties together, without anyone asking him to do so or paying him for it. Barnabas had recognised the potential of Saul as a Christian witness; he also realised that Saul would get nowhere if he was not accepted by the leaders of the Christian movement in Jerusalem. As so often in history, the unity of the church was at stake in a very pertinent way. It sounds so simple in Acts 9:27: "Barnabas took him, brought him to the apostles, and described for them. So, he went in and out among them in Jerusalem, speaking boldly in the name of the Lord." Barnabas told them that Saul had seen the Lord on the way to Damascus, that the Lord had spoken to him, and that he had openly preached in the name of Jesus in Damascus. These three pieces of testimony, on the authority of Barnabas, opened the door for Saul to be welcomed and taken up into the heart of the Jesus movement of that time. It was an important event in the history of the church, as portrayed by Luke. According to Acts, Saul's ministry would not have been authentic without this reconciliation between Saul and the church of Jerusalem.

Kritzinger $(2011,16)$ argues that what worked in Barnabas's favour, was that he had enough credibility on both sides of the conflict that he could act as a bridge-builder between them. Barnabas wanted to gather God's people together in unity, to build bridges of trust and acceptance between them, thus expressing this "mothering" ministry of God revealed in Jesus. Conflicts in church associations in the UPCSA require a "Barnabas" figure who has enough credibility on both sides of the conflict in order to serve as a mediator. The UPCSA is blessed with such ministers who can play a significant role in trying to bring reconciliation among the warring factions in the church associations. For instance, Buqa $(2012,103)$ makes reference to one minister in the Presbytery of Tshwane, who was the convenor of church associations and as a neutral person she was able to encourage various executive committee members of different associations to work together and find common ground. On the other hand, the UPCSA must guard against assigning such a role to ministers who have often failed to play the 
role of Barnabas the mediator, since they are a conflicted party by being members of associations.

However, this having been said, it is unfortunate that simple Christian values like reconciliation, repentance and acceptance were repudiated when the membership of two denominations had so much in common such as theology, liturgy and polity, and where past history was allowed to interfere in progress toward the future, where mutual welcome into that future would have been more appropriate and fruitful:

...reconciliation is about healing the past and building the future. Healing the past is necessary because otherwise the memories and consequences of what happened in the past can block any future directions we may wish to take. Building a different kind of future requires at least some measure of assurance that past trauma does not continue or is able to disrupt that building of the future by a Freudian "return of the repressed." (Schreiter 2013, 18, emphasis in original)

This involves time and great energy, as reconciliation is both a process and a goal; it is a "pre-eminence of grace over justice" (Kang 2013, 313). Clegg $(2006,129)$ emphasises this in expressing her understanding of reconciliation as:

... the structures and processes necessary to bring all elements of the cosmos into a positive life-giving relationship with God and one another, [a]s the telos of creation. It is at this point that the orders of creation and redemption overlap.

One of the reasons certain sections of the white membership cannot comprehend the conflicts in church associations, is that the membership of church associations, having been rooted in mission, were evangelised along with their cultures which were both fragile and resilient, where narrative is a significant source of identity. In this connection, Jørgensen (2013, 323) argues that consequently "any model of reconciliation is embedded within a particular culture and structure." Further, these same white members view mission as something that white people do to or for black people who are recipients of their missionary-oriented largesse. They cannot comprehend black people themselves being agents of mission. They have perpetrated division in their concept of church. In not one case throughout the UPCSA has a white congregation united with its former "mission" congregation since the UPCSA was established. Integration was initiated as a project of the newly formed UPCSA with a limited view of "uniting" black congregations existing in the same locality.

People who have experienced deep divisions have to reconstruct the story of themselves and their enemies if the wounds of the past are to heal in any measure. Such new narratives are important for strengthening the bonds of identity and community. They are the fruits of a "new creation" (Schreiter 2013, 27).

Bosch $(1991,475)$ reminds us that even a reconciled community is not a perfect community, for even mission in unity "presupposes tension. It does not presume 
uniformity," as this article has demonstrated with conflicts that have plagued the associations in the UPCSA. The tension calls us to "repentance" (Bosch 1991, 475476), which necessarily implies moving beyond the self to ensure solidarity with others. This is the essential meaning of love. Rohr $(2019,74)$ describes it as "a primal change of mind"; to "go beyond your mind"; and a "change of consciousness." In our woundedness and brokenness (Jørgensen 2013, 321) we are empowered to change our lives around through grace and engage in justice with the Other. As Rohr $(2019,88)$ expresses it, commenting on the story of Thomas and Jesus post-resurrection, it is: "believing that someone could be wounded and resurrected at the same time!" (emphasis in original) for these are "the universal, always available paths of transformation, because they are the only things strong enough to take away the ego's protections and pretensions." Rohr $(2019,89)$ refers to this as a "tangible" form of religion "that makes touching human pain and suffering the way into both compassion and understanding." It is a pity that this kind of thinking had not penetrated the void that separated the associations in the UPCSA.

A serious consequence of the dispute relating to the church associations is that the missionary outreach of the entire UPCSA has been significantly and negatively affected and has become a source of shame in its historical context, in which great things have been achieved in the past. Bosch $(1991,476)$ refers to this as mission in unity, where mission is a source and goal of unity:

To take up the deepest conflicts of the world into itself and to confront both sides there with the forgiving, transforming power that breaks and remakes them into a new community, with a new hope and a new calling. (West 1971, 270)

This is God's mission as we participate together in the reconciliation of the entire cosmos to God. Anything else is a source of shame and disgrace, as we continue to refuse to accept those whom God has made and claimed to be eminently acceptable.

\section{Conclusion}

The church associations were part of the momentous occasion which gave birth to the UPCSA in September 1999 through the organic union between the RPCSA and PCSA. Sadly, the denomination is still struggling with the issues affecting the amalgamation of the associations which provided the spirit that drove that defining moment. The conflicts of the church associations continue to hurt and damage the witness, work and unity of the UPCSA and that does not augur well for the union of the UPCSA. Over the years, there were a number of initiatives taken to broker a way forward and to find reconciliation, peace and unity. Unfortunately, such efforts have not yet yielded any positive results, since associations such as the UPWF and MCG are still struggling with unity within their ranks. In the interviews that Buqa (2012) conducted, he concluded that it appears as if church associations are used as a scapegoat by ministers, elders and members of the congregations of both the former RPCSA and PCSA, who are unwilling and find it difficult to embrace the union. Those who no longer hold positions of power 
in the new denomination and feel disgruntled, disguise their frustrations and anger and undermine the possibilities and potential of one of the few examples of church unions in a democratic South Africa. In such cases, the leadership of the church and the rank and file need to be vigilant and have a sense of discernment to ensure that church associations are no longer hijacked as a means to serve narrow sectarian interests. It seems all is not lost, as some of these associations continue to evangelise, and exercise ministry and community work, even if on a limited scale. They also offer care for retired ministers, provide grants and bursaries and support congregations. Such initiatives give one hope that the hurts, pains and suffering which many members had to endure due to conflicts in church associations, can be overcome. Furthermore, what is encouraging is that the leadership of the UPCSA continues to bridge the gap of divisions amongst the associations through church structures and continues to explore various options to address the issues surrounding the church associations. For instance, the General Assembly of 2012 passed a resolution instructing "The General Secretary to engage the services of Church based professional external mediators for the Associations which are acceptable to all parties involved, in accordance with the 2009 Executive Commission decision" (UPCSA, GA 2014, 77).

\section{References}

Bosch, D. J. 1991. Transforming Mission: Paradigm Shifts in Theology of Mission. Maryknoll: Orbis. https://doi.org/10.1177/009182969101900203.

Buqa, W. 2012. "Conflicts between the Church Associations of the UPCSA, with Special Reference to the Presbytery of Tshwane: A Narrative Approach.” MTh dissertation, University of Pretoria.

Clegg, C. 2006. "Between Embrace and Exclusion." In Explorations in reconciliation, edited by D. Tombs and J. Liechty. Aldershot: Ashgate.

Duncan, G. 2005a. "Reconciliation through Church Union in Post-Apartheid South Africa: The Uniting Presbyterian Church in Southern Africa.” Verbum at Ecclesia 26 (1): 35-63. https://doi.org/10.4102/ve.v26i1.212.

Duncan, G. 2005b. "State of the Union: The Uniting Presbyterian Church in Southern Africa, 1999-2004.” Studia Historiae Ecclesiasticae XXXXI (2) October: 189-219.

Duncan, G. 2006. "Ministerial Dress for Worship in Southern Africa Presbyterianism.” HTS 62 (3). https://doi.org/10.4102/hts.v62i3.393.

Duncan, G. 2007. "Partnership in Mission: A Critical Historical Evaluation of the Relationship between 'Older' and 'Younger' Churches with Special Reference to the World Mission Council of the Church of Scotland." PhD thesis. Pretoria: University of Pretoria. 
Jørgensen, K. 2013. "Hope in a Fragile World: The Reconciling Mission of the Church." In Mission as ministry of reconciliation, edited by R. Schreiter and K. Jørgensen. Oxford: Regnum, 321-330. https://doi.org/10.2307/j.ctv1ddcpgx.34.

Kang, L. Y. 2013. "Conspiracy, Trust and Healthy Scepticism: The Reconciling Church in Hong Kong Politics.” In Mission as Ministry of Reconciliation, edited by R. Schreiter and K. Jørgensen. Oxford: Regnum, 309-320. https://doi.org/10.2307/j.ctv1ddcpgx.33.

Karecki, M. 1999. Patterns of Mission Praxis. Only study guide for CMM112-Q. Pretoria: University of South Africa.

Kritzinger, J. N. J. 2011. "Reconciling Encounters in Luke-Acts: A South African Missional Interpretation.” Unpublished Paper.

Makofane, K. M. 2009.” The Moratorium Debate in Christian Mission and the Evangelical Lutheran Church in Southern Africa." MTh dissertation, University of South Africa.

Preston, A. B. 2007. "An Appraisal of the Spirituality of Methodist Women in Post-Apartheid South Africa.” MTh thesis, University of South Africa.

Progress Report from the Special Committee on Reformation 2002.

Report on the Mediation Work of the Uniting Presbyterian Church in Southern Africa to the 11th General Assembly of 2014.

Rohr, R. 2019. The Universal Christ. New York: Penguin Random House.

Schreiter, R. 2013. "The Emergence of Reconciliation as a Paradigm of Mission." In Mission as Ministry of Reconciliation, edited by R. Schreiter and K. Jørgensen. Oxford: Regnum, 9-29. https://doi.org/10.2307/j.ctv1ddcpgx.5.

UPCSA. 2000. Proceedings and Decisions of General Assembly. Johannesburg: UPCSA.

UPCSA. 2002. Proceedings and Decisions of General Assembly. Johannesburg: UPCSA.

UPCSA. 2003. Proceedings and Decisions of General Assembly. Johannesburg: UPCSA.

UPCSA. 2004. Papers for the 6th General Assembly. Johannesburg: UPCSA.

UPCSA. 2005. Proceedings and Decisions of General Assembly. Johannesburg: UPCSA.

UPCSA. 2007. Papers, Proceedings and Decisions of the Executive Commission. Johannesburg: UPCSA.

UPCSA. 2008. Papers for the 8th General Assembly. Johannesburg: UPCSA.

UPCSA. 2009. Papers, Proceedings and Decisions of the Executive Commission. Johannesburg: UPCSA. 
UPCSA. 2014. Papers, Proceedings and Decisions of the Executive Commission. Johannesburg: UPCSA.

UPCSA. 2015. Papers, Proceedings and Decisions of the Executive Commission. Johannesburg: UPCSA.

Vellem, V. 2007. The Manual of Faith and Order of The Uniting Presbyterian Church in Southern Africa. Johannesburg: Parktown.

West, C. 1971. The Power to be Human: Toward a Secular Theology. New York: Macmillan.

Xapile, S. P. 1994. "Unity Negotiations between the Bantu Presbyterian Church and the Presbyterian Church of Southern Africa 1959-1971." MA Dissertation, University of Cape Town. 